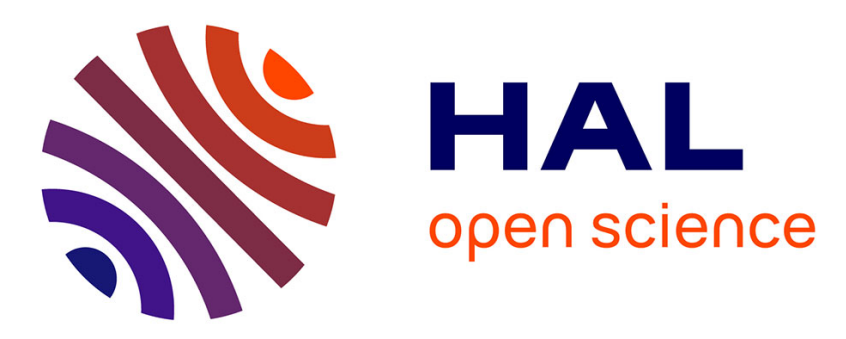

\title{
Drawing a chip environmental profile: environmental indicators for the semiconductor industry
}

\author{
Aurélie Villard, Alan Lelah, Daniel Brissaud
}

\section{To cite this version:}

Aurélie Villard, Alan Lelah, Daniel Brissaud. Drawing a chip environmental profile: environmental indicators for the semiconductor industry. Journal of Cleaner Production, 2015, 86, pp.98-109. 10.1016/j.jclepro.2014.08.061 . hal-01063777

\section{HAL Id: hal-01063777 https://hal.science/hal-01063777}

Submitted on 27 Nov 2014

HAL is a multi-disciplinary open access archive for the deposit and dissemination of scientific research documents, whether they are published or not. The documents may come from teaching and research institutions in France or abroad, or from public or private research centers.
L'archive ouverte pluridisciplinaire HAL, est destinée au dépôt et à la diffusion de documents scientifiques de niveau recherche, publiés ou non, émanant des établissements d'enseignement et de recherche français ou étrangers, des laboratoires publics ou privés. 


\title{
Drawing a chip environmental profile: Environmental indicators for the semiconductor industry
}

\author{
Aurélie Villard, Alan Lelah, Daniel Brissaud \\ Univ. Grenoble Alpes, Laboratoire G-SCOP, Grenoble, France \\ Corresponding author:alan.lelah@g-scop.grenoble-inp.fr
}

\begin{abstract}
The semiconductor industry plays an ever-increasing role in society, providing microelectronic components called chips that are used in a wide variety of electronic applications. The rapid increase of the production of chips is responsible for considerable effects on the environment during the different phases of their lifecycle. In spite of increasing pressure from stakeholders to control these effects, no international standard or agreement has yet been established. In this context, the paper proposes a set of environmental indicators that take into account the most serious damages induced by these products.

To establish an exhaustive list of indicators, the specificities of the semiconductor branch are first analyzed in literature, identifying pressures on the sector coming from the downstream chain - chip buyers and users - and finally by analyzing data from industrial case studies. In order to highlight the most significant direct and indirect impacts, each aspect of the chips' life cycle phases is studied independently. The indicators reflect the particularities of the industry and point out the major impact categories. They can be therefore be used for standardized environmental analysis of microelectronic products. The paper retains seven environmental indicators: resource depletion, eutrophication, water stress, toxicity, summer smog and local electrical consumption. The final set of indicators will help draw the environmental profile of the microelectronic chips over the full life cycle of the products. It is a step towards necessary standardization in the microelectronic industry. The indicators are consistent with current state of the art and can evolve as progress is made on the definition and calculation of new indicators.
\end{abstract}

Keywords: environmental impacts; indicators; semiconductor industry; chips; life cycle assessment.

\section{Highlights}

- 7 key environment indicators, specific to the semiconductor industry, are proposed

- The indicators are based on observations in microelectronic manufacturing plants

- They contribute to standardise the environmental profile of microelectronic chips

- The indicators can be used over the full product life cycle

\section{List of Abbreviations and Acronyms}

$\begin{array}{ll}\text { CO } & \text { Carbon Monoxide } \\ \text { CML } & \text { Chain Management by Life Cycle Assessment } \\ \text { CVD } & \text { Chemical Vapour Deposition } \\ \text { DPSIR } & \text { Driving force, Pressure, State, Impact, Response } \\ \text { ESIA } & \text { European Semiconductor Industry Association } \\ \text { EuP } & \text { Eco-Design of Energy-using Products } \\ \text { GHG } & \text { Greenhouse Gas } \\ \text { IC } & \text { Integrated Circuit } \\ \text { ISO } & \text { International Organization for Standardization } \\ \text { ITRS } & \text { International Technology Roadmap for Semiconductors } \\ \text { ITU } & \text { International Telecommunication Union } \\ \text { KEPI } & \text { Key Environmental Priority Indicator } \\ \text { LCA } & \text { Life Cycle Assessment } \\ \text { LCI } & \text { Life Cycle Inventory } \\ \text { NGO } & \text { Non Government Organization } \\ \text { NOX } & \text { Nitrogen Oxides } \\ \text { OECD } & \text { Organization for Economic Co-operation and Development } \\ \text { PFC } & \text { Perfluorocarbon } \\ \text { RoHS } & \text { Restriction of the use of Hazardous Substances } \\ \text { SETAC } & \text { Society of Environmental Toxicology and Chemistry } \\ \text { TRACI } & \text { Tool for the Reduction and Assessment of Chemical and other Environmental Impacts } \\ \text { VOC } & \text { Volatile Organic Compound }\end{array}$




\section{Introduction}

The relatively low cost of production of microelectronic components, also called chips or integrated circuits (ICs), has made computers, mobile phones and other electronic devices inextricable parts of the structure of modern societies. Their very fast expansion into all sectors of the economy contributes to worrying effects on the environment: pollution in manufacturing plants; depletion of raw materials; electricity consumption during use; and accumulation of electronic waste, amongst others.

This trend justifies current efforts to improve knowledge on the environmental risks and impacts of products in the microelectronic industry. This paper starts with the different potential impacts of the industry and determines the significant indicators that could be used to monitor the environmental consequences of the activity. Different indicators are currently available to characterize environmental impacts so the paper does not develop new ones but proceeds with state of the art indicators.

Life Cycle Assessment (LCA) is identified as a powerful technique to present a global vision of the impacts generated by products. Results are presented in the form of a profile, providing a baseline to control the environmental state of the product and suggest ways to improve it. In theory, the schema should account for all the aspects: climate change, eco-systems quality, biodiversity, etc., without minimizing or intensifying one effect rather than another. The reason for considering all the aspects is to avoid impact transfers: attempts to improve one type of impact can deteriorate another one, which had hitherto been neglected or not at all regarded as important for the industry. However, each industry has its own particular concerns and should act in priority to reduce the most significant impacts it produces and determine the adequate indicators to guide this.

The choice of indicators can be made by considering factors such as image, communication on previously achieved efforts and the ease of data collection (Olsthoorn et al., 2001), however, a scientific determination of indicators requires a deep analysis of every stage of the lifecycle. The effect on the environment of a product can be visualised through the approach developed by the OECD called DPSIR: Driving force, Pressure, State, Impact, Response (Lütz and Felici, 2008). It was developed to clarify the causalities between the actions of society and the consequences on the environment and ecosystems, and also to identify the needs for action. Furthermore, according to $\mathrm{ISO}^{2}$ 14031 (ISO, 1999), the selection and definition of environmental performance indicators has to take into account the significance of environmental aspects, the influence on the aspects and policy of the organization concerned and the views of other stakeholders. Indeed, the strategic positioning of a company is motivated essentially by external environmental, economic and social facets.

In the semi-conductor sector it has mainly been external pressure that has, in the past, pushed the industry to learn more about the environmental impacts of its products. As a chip is only a small part of electronic applications, it is not intended for the general public but for industrial clients and has therefore not been a primary target of NGOs (Non Government Organizations) and consumers associations. Today, concerns are driven by generic stakeholder considerations, materialised by demands from extra-financial marking agencies. These agencies deliver ethical indexes like the Dow Jones Sustainability Index and usually call for reports on three major themes: climate strategy, water related risks and hazardous chemicals. In recent years, life cycle thinking has appeared in regulations across the world, most often initiated by the European Union (Szendiuch and Schischke 2007): RoHS (Restriction of the use of certain Hazardous Substances) (European Commission, 2002a), WEEE (Waste Electrical and Electronic Equipment) (European Commission, 2002b) and EuP (Eco-Design of Energy-using Products) (European Commission, 2005). These directives extend the responsibility of producers to the full product lifecycle. Expectations from society can therefore be taken as the first motivation to study the environmental impacts of the micro-electronic products.

The second motivation comes from industrial applications that need to evaluate the environmental potential of consumer products incorporating semi-conductors. The environmental performances of the applications are dependent on the chips embedded inside. The selection of significant aspects of a chip cannot therefore be detached from customer demands. However, indicators should cover the needs of the industrial customers without losing the original microelectronic specificities. Electronic and computer industries are the historical customers of the microelectronic industry but lately, many new applications with electric and electronic devices have appeared and common appliances, like coffee machines, cars, ink cartridges, light bulbs, medical applications, etc. integrate electronic functions. The diversity of customer markets tends to multiply environmental obligations. First of all, the electronic sector as a whole has been facing an increasing problem of electronic waste leading to the legislative

\footnotetext{
${ }^{1}$ OECD: Organization for Economic Co-operation and Development - http://www.oecd.org

${ }^{2}$ ISO: International Organization for Standardization - http://www.iso.org/iso/home.html
} 
frameworks mentioned above. In addition, the ITU ${ }^{3}$ has been focusing on the greenhouse gas (GHG) emissions and energy consumption. Although the scope may seem restricted due to the international focus on GHGs, according to recent working groups (ITU, 2010), other environmental impacts like raw material depletion or water stress would be tackled later. Furthermore, the automotive sector insists on the use phase (limitation of air exhausts) and end-of-life (European Commission, 2002). In this way each particular applicative sector introduces new requirements for the semiconductors.

Finally, the third motivation comes from microelectronic associations that have decided to take the lead on environmental concerns in their own industry. Chip manufacturers are regrouped in associations, such as ESIA ${ }^{4}$, that defend interests on a national, regional or global level. These associations reflect the trends within the sector in their reports. ITRS ${ }^{5}$, sponsored by the five leading chip manufacturing regions in the world: Europe, Japan, Korea, Taiwan, and the United States, includes an Environment Safety and Health Summary in their yearly roadmap (ITRS, 2013). However, ITRS is essentially a technology roadmap and the document insists on the needs for more robust and rapid assessment methodologies for chemicals, global warming, water and energy, along with some equipment life-cycle issues (ITRS, 2013). Another international consortium of leading semiconductor manufacturers, SEMATECH $^{6}$ (2009) has developed Key Environmental Priority Indicators (KEPIs) for the microelectronic sector as "specific expressions that provide information about an organization's environmental performances" (ISO, 1999). These KEPIs cover restricted concerns: global warming, water resource, chemical consumption and waste generation impacts. No knowledge management and classification of chemicals are available so no severity analysis can be performed. The indicators are handy for benchmarking but not linked to real product pressure. The purpose of the Life Cycle Assessment White Paper published by SEMATECH (2002) was to gather information about chiprelated LCA activities already completed or still under development. The white paper advised that in coming years a consensus be developed on lifecycle impact assessment methods and tools.

To help the industry formalise information on environmental concerns, this paper contributes to develop a suitable set of environmental indicators for the semiconductor industry and finally supply scientific information for the definition of standards. The indicators will help clarify the environmental load of a chip and alert the semiconductor industry on environmental issues for which it has real responsibilities in a lifecycle perspective. It provides elements to help industrial and public policies decrease the environmental footprint of activities by acting on lifecycle impacts. Moreover, seeing that environmental constraints should be considered in early design phases (Gehin et al., 2008), the profile will be very useful for eco-design perspectives. The designer can thereby decrease or, at least, limit, environmental effects of the future chips. The paper is organised as follows. Section 2 establishes a state of the art of knowledge at a sectorial level of interactions of the microelectronic industry and the environment. Section 3 studies the chips' lifecycle stages and derives a list of impact categories according to literature and the experience of practitioners. From these results, section 4 determines the nature of the strongest pressures and consequently proposes a set of indicators that account for the important aspects of the microelectronic activity. Finally conclusions are drawn in section 5 on the indicators that the semiconductor industry could lean on to develop environmental profiles of the chips.

\section{State-of-the-art of environmental knowledge in the microelectronic sector}

Characterizing the environmental impacts of industrial activities can generally be done from two different methodological standpoints: top-down, based on environmental input output analysis or bottom-up, based on process analysis (Wiedmann and Minx, 2008, Scipioniet et al., 2012). Input output analysis is useful to determine the effects of all economic activities at a sector level, while process analysis is used to measure impacts of individual products from cradle to grave (Wiedmann and Minx, 2008). Pure input output approaches are not specific enough to treat integrated product policy, assessment of individual products, or the benchmarking of single business against the sector average (Minx et al., 2009) and a product level method and is more adapted to a lifecycle approach (Scipioniet et al., 2012). However it requires appropriate definition of system boundaries (Wiedmann and Minx, 2008). For example, the Carbon footprint indicator identifies three levels of analysis, or scopes: Scope 1 reports GHG emissions owned or controlled by the industry; 2, covers indirect emissions associated with the external electricity supply; while 3, considers other indirect emissions associated with the operations of the organization concerned (Minx et al., 2009). Scope 3 is not relevant in this study.

\footnotetext{
${ }^{3}$ ITU: International Telecommunication Union - http://www.itu.int/en/Pages/default.aspx

${ }^{4}$ ESIA: European Semiconductor Industry Association - http://www.eeca.be/esia/home

${ }^{5}$ ITRS: International Technology Roadmap for Semiconductors - http://www.itrs.net/home.html

${ }^{6}$ SEMATECH: http://sematech.org/index.htm
} 
After a brief description of the semiconductor lifecycle to introduce the major stages semiconductor products go through, this section reviews scientific literature and resumes the state of environmental knowledge in the industry.

\subsection{Semiconductor lifecycles}

A chip is basically a silicon substrate to which complex surface treatment processes are applied. As the component size constantly decreases on the nano and micrometric scale, the manufacturing phase becomes more and more complex. The major specificity lies in the fact that a lot of secondary materials used during manufacturing do not remain on the final chip (Williams, 2002). There are two types of production plants involved in the industry: front-end plants, producing wafers containing a large number of semiconductor chips and back-end plants that package the chips. The package provides protection and electrical connexions when the chip is integrated onto a circuit board.

The same chips can be embedded in different electronic equipment. A microchip is environmentally neutral during its use, excepting the energy required to make it work. After disposal, it can contaminate soils, water and air because of the presence of metals and dangerous compounds like lead used in soldering. Other than potentially uncontrolled emissions, e-waste management generates issues from intensive electricity, water and chemical consumption, whatever the end-of-life process used.

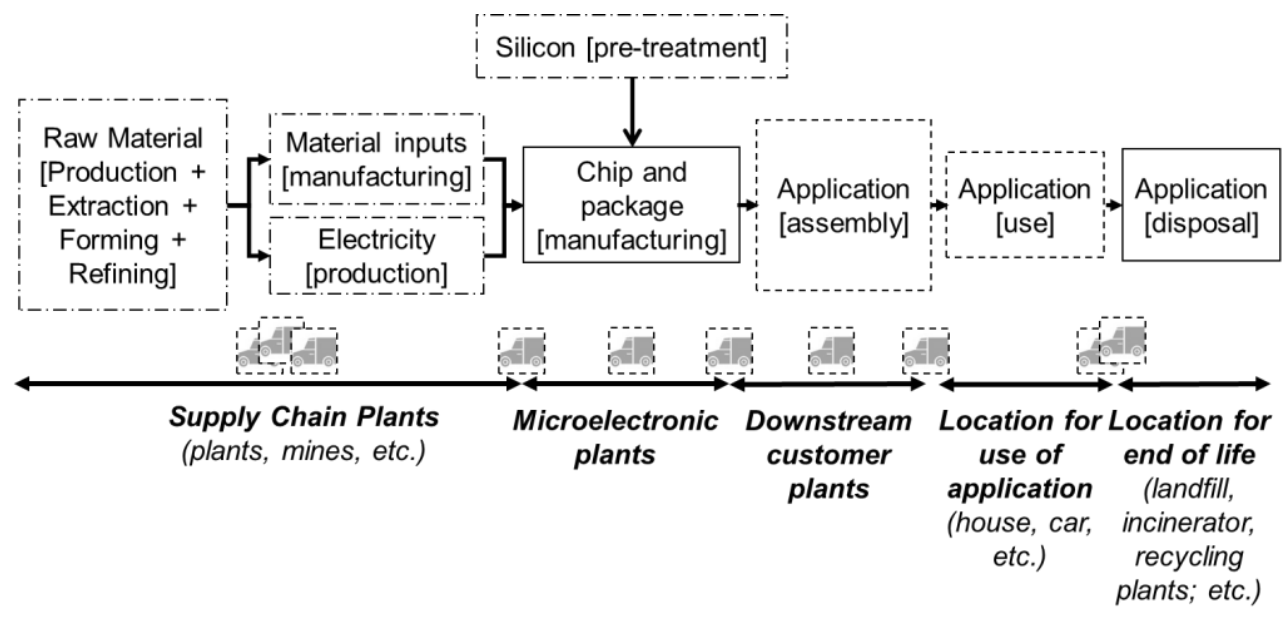

Intermediary transportation

Environmental data taken from LCA databases

General considerations for determining impact categories

Fig. 1. General phases in a component lifecycle.

Figure 1 illustrates the general phases involved in a microelectronic component lifecycle. The life cycle can be separated in two: the production of the microelectronic chips and their applications. Production starts with the extraction and processing of raw materials, including silicon before entering the microelectronic manufacturing plants. The actual microelectronic manufacturing comprises two stages: chip manufacturing and packaging, which are not usually done in the same plants. The main focus of the case study is on these two stages. In this study, the extraction and processing of raw materials is considered as being relatively well documented in existing lifecycle inventory (LCI) databases and therefore data concerning these phases is taken directly from them.

After production, the chips are integrated into the final application. It is the application that is used and disposed of in the end. Intermediary transportation phases interlace within these phases. Microelectronic chips are integrated into a wide variety of applications, so use and transport are too vast and varied for detailed study here. These phases are therefore only considered in general here, in order to determine their part of impacts and the categories involved (see Section 3.1). 


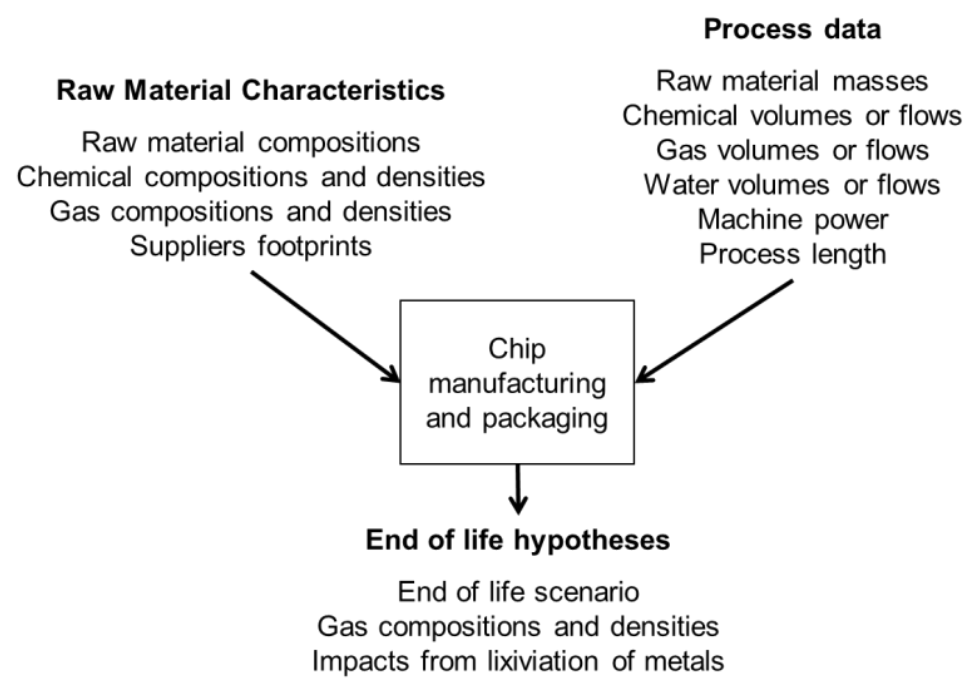

Fig. 2. General phases in a component lifecycle.

Figure 2 resumes the details that have to be accounted for to determine the environmental impacts of the microelectronic chips. From the supply chain, it is necessary to identify raw material compositions; chemical compositions and densities; gas compositions and densities; as well as the suppliers footprints. During microelectronic manufacturing and packaging, it is necessary to specify raw material masses; chemical, gas and water volumes or flows; machine power and the length of the processes. Hypotheses have usually to be made for the future end of life scenarios and the compositions and densities of the gases emitted must be estimated as well as polluting effects from the lixiviation of metals.

\subsection{Scientific reviews in literature}

Compared to other sectors, microelectronics seems to fall behind in the environmental field. Analysis of the current state of art regarding LCA of microelectronic chips alone is insufficient to draw the profile of this complex industrial sector. Indeed generic literature reviews showed that very few LCArelated cases of study from industrial initiatives have been published (Schischke et al., 2001; Taiariol et al., 2001; Dickinson, 2002). Moreover, Schmidt et al. (2011) found that the present eco-invent dataset for wafers fabricated for ICs was obsolete because it "shows large differences" with the results from deeper studies.

There are several reasons to explain the limited state of art compared to other industries. First of all, up to now, the microelectronic sector has replied to external pressure without particularly having to change its natural strategic roadmaps. The semiconductor industry is essentially driven by Moore's law (Shaller, 1997), which states that the number of transistors that can be placed inexpensively on an IC doubles approximately every two years. This trend tends to induce a beneficial effect on the environment because there are more components per wafer (the unit of production) for quasi equivalent manufacturing flows between different generations. Moreover, smaller transistor devices also naturally consume much less energy in use. Technological roadmaps for packaging also tend to reduce the mass of packaging and add the possibility of encapsulating several components in one package, which further reduces raw material consumption. Besides, the application of the RoHS directive alone strongly contributes to reduce impacts on human health, especially during end-of-life treatment. Another possible explanation is that microelectronic applications are reputed to consume much less energy than other traditional industrial sectors. However, as Bonvoisin et al. (2014) remarked, although microelectronic chips embedded into applications provide services that may help to avoid impacts, they use impact-intensive semiconductor technologies and it is therefore necessary to insure that the impact reductions they allow at least balance the impacts generated by the infrastructures they rely on.

The scientific community has therefore expressed concern on the LCA quality of microchips. The evergrowing technological complexity is a major obstacle for LCI in the manufacturing phase (Schischke and Griese, 2004). Since most existing LCI databases had been piloted by other industries, data reliability of models for dedicated materials (moulding resins, ultrapure chemicals, pre-doped wafers or packaging substrate) is too low for microelectronic purposes (Plepys, 2004). These singularities hinder the realization of in-depth analysis at a sectorial scale. 


\subsection{The profession's knowledge on environmental responsibility}

To compensate lacking literature and understand how the microelectronic industry faces environmental questions during production, eight interviews with actors of environment strategies and policies were conducted in a leading semiconductor company. The company is well representative of the sector: factories are located worldwide; all the design centres and manufacturing plants are certified ISO14000; the products, designed and manufactured internally, are competitive in the international market.

The professionals that were interviewed are corporate business managers dealing with international legislation and external pressure; environmental experts in manufacturing sites dealing with local production concerns; and environment managers dealing with external pressure from regulations and customers in design centres, where the chips are actually designed.

The question asked was to "classify the most sensitive environmental themes your activity has to manage". Critical themes were ranked with plus and minus marks (explained in Table 1-a). A mark was given for environmental reporting indicating the existence of stakeholder pressure: 1 if the pressure existed, 0 if not. The categories proposed were selected beforehand according to their availability in LCA software, like $\mathrm{Gabi}^{7}$ or SimaPro ${ }^{8}$. As environmental issues can be very different, front and backend sites were studied separately. The results of the interviews are summarised in Table 1-a.

Table 1-a. Expert ranking of environmental concerns in manufacturing plants

\begin{tabular}{|c|c|c|c|c|}
\hline IMPACTS & 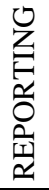 & 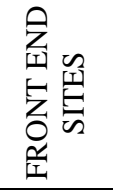 & 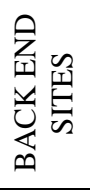 & $\begin{array}{l}\text { REASON FOR IMPACT CONTROL: } \\
\text { DESIRABLE LEVEL OF SITE RESPONSIBILITY }\end{array}$ \\
\hline $\begin{array}{l}\text { Toxicity in } \\
\text { water }\end{array}$ & 1 & ++ & +++ & $\begin{array}{l}\text { Many dangerous chemicals are consumed; the risk of toxic } \\
\text { effects on health and ecosystems by waste water exists }\end{array}$ \\
\hline $\begin{array}{c}\text { Global } \\
\text { warming }\end{array}$ & 1 & +++ & +++ & $\begin{array}{l}\text { Direct - perfluorocarbons (PFCs) - or indirect - energy - } \\
\text { emissions } \\
\text { The level of severity depends on the efficiency of PFC treatment } \\
\text { units } \\
\text { Intensive use of electricity }\end{array}$ \\
\hline $\begin{array}{l}\text { Resource } \\
\text { depletion }\end{array}$ & 1 & +++ & +++ & Intensive use of raw materials \\
\hline Water stress & 0 & +++ & + & Intensive use of ultrapure water \\
\hline $\begin{array}{c}\text { Water } \\
\text { Acidification }\end{array}$ & 0 & ++ & + & $\begin{array}{l}\text { Many acids are consumed; the severity level depends on the } \\
\text { sensitivity of local ecosystems and the efficiency of waste water } \\
\text { treatment plants }\end{array}$ \\
\hline Eutrophication & 1 & $=/++$ & + & $\begin{array}{l}\text { Many acids are consumed; the severity level depends on the } \\
\text { sensitivity of local ecosystems and the efficiency of waste water } \\
\text { treatment plants }\end{array}$ \\
\hline $\begin{array}{c}\text { Air } \\
\text { acidification } \\
\end{array}$ & 1 & $+/++$ & $=$ & $\begin{array}{l}\text { A few acidifying gases are used; the majority of emissions is } \\
\text { controlled by air treatment units; site-dependent }\end{array}$ \\
\hline Summer smog & 1 & $++/+++$ & ++ & $\begin{array}{l}\text { Emissions in air due to general plant functioning; the severity } \\
\text { level depends on the sensitivity of local ecosystems and the } \\
\text { efficiency of Volatile Organic Compounds (VOCs) treatment } \\
\text { units }\end{array}$ \\
\hline Human health & 0 & + & + & $\begin{array}{l}\text { A few dangerous substances have to be managed for worker } \\
\text { safety }\end{array}$ \\
\hline Waste & 1 & $=$ & + & Considerable quantity of plastic waste; variable rate of recycling \\
\hline Noise & 0 & $=$ & $=$ & \\
\hline $\begin{array}{c}\text { Ozone layer } \\
\text { depletion }\end{array}$ & 0 & $=$ & $=$ & \\
\hline Toxicity in air & 0 & $=$ & $=$ & $\begin{array}{l}\text { A few toxic gases are consumed; All are under control by air } \\
\text { treatment units }\end{array}$ \\
\hline $\begin{array}{c}\text { Land } \\
\text { occupation }\end{array}$ & 0 & $=$ & $=$ & \\
\hline Toxicity (soil) & 0 & $=$ & $=$ & \\
\hline Smell & 0 & $=$ & $=$ & \\
\hline
\end{tabular}

\footnotetext{
${ }^{7}$ Gabi: http://www.gabi-software.com

${ }^{8}$ SimaPro: http://www.pre-sustainability.com/simapro
} 
Table 1-a shows that in the manufacturing stages, three levels can be discerned. A first group concerns major issues of water toxicity, global warning, resource depletion and water stress. The group highlights intensive use of electricity, raw materials and chemicals. These categories are generally covered by environmental reporting, except for the notable case of water stress. The second group poses fewer problems and results from the consumption of acids (water and air acidification and eutrophication); air emissions (summer smog); manipulation of dangerous substances (human health) and generation of waste (waste). Here, most of the categories are covered by environmental reporting except for water acidification and waste. The last group is not considered as an important concern of the industry: noise, ozone layer depletion, air and soil toxicity, land occupation and smell.

Some differences can be seen between the front and back-end sites. The major difference in the front end sites results from the intensive use of ultra-pure water affects the water stress which is far less important in the back-end sites. Also, more intensive use of acids affects the front-end sites more than the back-end (acidification and eutrophication), however in some front end-sites adequate treatment of waste water and air reduces, or eliminates these problems. Back-end sites have more difficulties with water toxicity and waste due to the use of metals.

As design and manufacturing view-points are very different, they were also treated separately. The results from the design centre interviews are summarised in Table 1-b.

Table 1-b. Expert ranking of environmental concerns in design centres

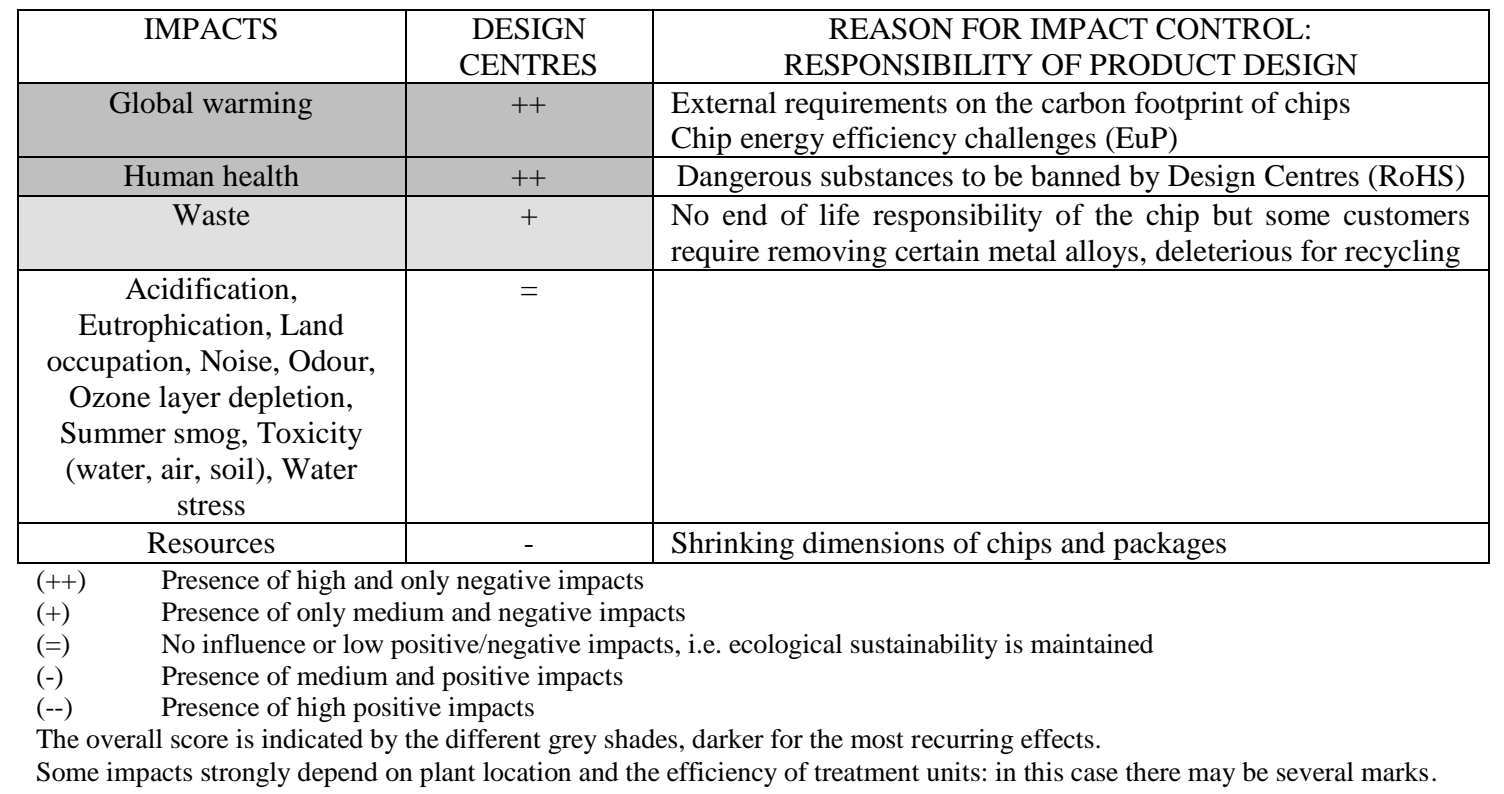

Design has lower effects on the environment. Designers do not modify the production process itself; they however influence the use phase of the products to a great extent and do manually intervene on partially manufactured chips or packages for research and development purposes. The effects on the environment can be classed into three groups of categories. The major concerns are from global warming (design greatly effects the use phase of the chips, and therefore electrical consumption) and human health (manual intervention for research and development purposes). Then comes waste that is not directly a problem of design, but rather because certain customers prohibit certain alloys that affect recycling adversely. The other categories are not directly affected by design choices, except for resources, but in this case, technological evolutions generally have a positive effect because of shrinking sizes of chips and packages.

\subsection{The Case of Rare Earth Elements}

Recently, there have been growing concerns on the supply of rare earth elements (RREs) due to high market volatility and supply uncertainties from China (Golev et al. 2014). REEs enter into the fabrication of microelectronic products during different life cycle phases. However, precise information is not very easy to obtain and open sources are scarce. USGS ${ }^{9}$ provides statistics and other information. Table 2 resumes major uses of REEs in products in the USA.

\footnotetext{
${ }^{9}$ USGS: US Geological Survey: http://minerals.usgs.gov/minerals/pubs/commodity/rare_earths/
} 
Table 2. Relative use of REEs for different application categories (extracted from Long, 2011)

\begin{tabular}{|l|c|}
\hline Use Category & Market Share by Volume (\%) \\
\hline Catalysts & 22 \\
\hline Magnets & 22 \\
\hline Metal alloys & 20 \\
\hline Polishing & 9 \\
\hline Glass & 9 \\
\hline Phosphors & 5 \\
\hline Other & 13 \\
\hline
\end{tabular}

In the case of microelectronics, REEs cited in literature (see for ex. Binnemans et al., 2013; Long, 2011) essentially cover application products rather than actual semiconductor ICs. Devices like hard drive disks (magnets); nickel metal hydride batteries; glass (digital cameras); display panels; ceramic capacitors etc. often include REEs (Long, 2011). During the fabrication phase of semiconductor ICs, Cerium is used in chemical polishing processes (Bleiwas and Gambogi, 2013), while REEs will be used in future ultra-thin oxides (Iwai and Ohmi, 2002). Currently, Praseodymium and Samarium are used for their magnetic properties in integrated MRAM circuits. A boom in the use of REEs in the semiconductor industry is expected in 2018.

According to Golev et al. (2014) REE processing is characterized by high levels of water consumption, energy inputs and chemical use. Land allocation can also be significant for both mining and processing operations, as well as for the tailings dams, and long term storages of the radioactive materials (Golev et al., 2014). Recycling techniques have appeared recently, such as for lamp phosphors; nickel metal hydride batteries; and magnets but concern only relatively small quantities (Binnemans et al., 2013). Current recycling processes focus mainly on REEs in magnets (USGS, 2014). Recycling is however not well developed and neglected for semiconductors today, because of technical difficulties as well as the small quantities in play (Binnemans et al., 2013, Golev et al. 2014).

\subsection{Discussions on environmental knowledge in the industry}

The observations made in this section consolidate first impressions that the knowledge on chip lifecycles is weak, even within the microelectronic companies, and needs to be reinforced. Although the evaluations were subjective and qualitative, it was not easy to distinguish how the chips really impact the environment from the simple expression of external international pressure. Furthermore, the "electronification" of society made it difficult to define a "standard chip" that could be used as a reference for discussion.

External pressures converge on specific concerns: climate change, energy saving, resource conservation, e-waste and water consumption. However, these consensual aspects provide a narrow scope to the issue and depend on the application or on the particular case and are not scientifically proved. To determine an environmental profile of a chip, an international consensus is necessary to characterise the impacts of the semi-conductor sector activities. The state-of-the art showed that life cycle thinking is not yet mature in the sector and we can conclude on the need to define standards for reporting on chip performance. The definition of standard indicators must meet stakeholder expectations, ensure that the microelectronic sector is responsible in relevant environmental issues and make comparison of chip profiles possible.

\section{Environmental impacts of microelectronic components}

This section aims to determine a complete list of significant environmental pressures by identifying the flows during the chip lifecycles that cause most of the environmental changes. To do so, a methodology including both direct and indirect impacts is proposed. The direct impacts can be directly controlled by chips manufacturers. Indirect impacts include all the effects that result from the purchase and the use of the chip, the manufacturing of raw materials, the production of energy to use the chip and chip disposal.

\subsection{Repartition of the environmental impacts of a chip during the life cycle phases}

As literature is quite poor, a LCA study was performed in an industrial context with one of the international leaders in the semi-conductor field in 2009 (Villard, 2009). It was carried out on four representative products of the industry: a microcontroller embedded in cars, a security card managing access to television, a memory for play stations and a circuit board with several chips used for battery control in cell phones. The results of the study are displayed in figure 3 . They show that for global 
warming, the most significant aspects of a chip are alternatively related to manufacturing and use by the end-user.

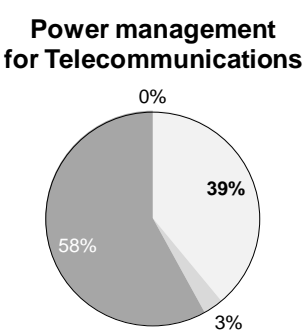

Micro Controller for Cars

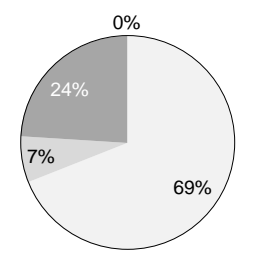

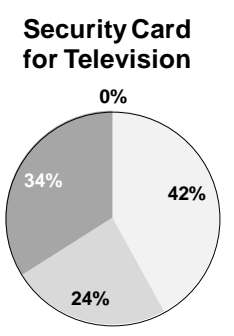

Manufacturing
Transport
Use
End of life

Memory

for Play Stations

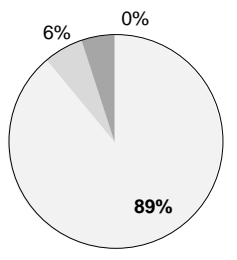

Fig. 3. Carbon dioxide emissions (IPPC) in 4 case studies (Villard, 2009).

These results agree with other results reported in the recent state of the art. Higgs et al. (2009) and Boyd et al. (2010) showed that for memories and compilation logic components the largest impacts were in the use phase. However they cannot be generalised to all chips. Schmidt et al. (2011) studied manufacturing and found that the contribution of the value chain compared to the whole manufacturing impact varied from $15 \%$ to $98 \%$ in function of the damage categories of IMPACT $2002+{ }^{10}$ indicators. Detailed results for manufacturing, use and transport phases of a current microelectronic product assessed by Simapro $^{8}$ using IMPACT2002+ indicators are provides in Table 3 (Villard, 2009).

Table 3. Relative Impacts according to IMPACT 2000+ for a microelectronic product (approximations based on Villard, 2009)

\begin{tabular}{|c|c|c|c|}
\hline IMPACT CATEGORY & MANUFACTURING & USE & TRANSPORT \\
\hline Carcinogens & $85 \%$ & $10 \%$ & $5 \%$ \\
\hline Non-carcinogens & $95 \%$ & $5 \%$ & $1 \%$ \\
\hline Respiratory inorganics & $40 \%$ & $40 \%$ & $20 \%$ \\
\hline Ionizing radiation & $5 \%$ & $95 \%$ & $1 \%$ \\
\hline Ozone layer depletion & $70 \%$ & $10 \%$ & $20 \%$ \\
\hline Respiratory organics & $45 \%$ & $15 \%$ & $40 \%$ \\
\hline Aquatic ecotoxicity & $40 \%$ & $55 \%$ & $5 \%$ \\
\hline Terrestrial ecotoxicity & $50 \%$ & $40 \%$ & $10 \%$ \\
\hline Terrestrial acid/nutri & $35 \%$ & $35 \%$ & $30 \%$ \\
\hline Land occupation & $30 \%$ & $30 \%$ & $40 \%$ \\
\hline Global warming & $40 \%$ & $35 \%$ & $25 \%$ \\
\hline Non-renewable energy & $10 \%$ & $80 \%$ & $10 \%$ \\
\hline Mineral extraction & $99 \%$ & $1 \%$ & $0 \%$ \\
\hline
\end{tabular}

For Boyd et al. (2010) studying the manufacturing of several generations of integrated circuits, this same contribution varied from $9 \%$ to $28 \%$ in function of the different damage categories considered

${ }^{10}$ IMPACT2002+: Impact assessment methodology originally developed at the Swiss Federal Institute of Technology - Lausanne - http://www.impactmodeling.net/ 
with TRACI $^{11}$ (Bare, 2002). These results were based on front-end production. In the internal case study carried out here, the contributions, including the back-end, vary from 6 to 58\%. Moreover according Williams (2004), the scope for LCA of a chip must focus in priority on the secondary raw materials used by the processes rather than the material structure. These results lead us to conclude on the importance of separating the impacts from the manufacturing plants and the impacts due to the value chain before manufacturing and after manufacturing.

\subsection{Impacts of the manufacturing plants}

A top-down approach considers the impacts of manufacturing plants as a whole. It considers both manufacturing operations and facilities. Chip manufacturing requires an extremely clean environment. This involves energy intensive heating, ventilation and air conditioning units. According to a report of Lawrence Berkeley National Laboratory (2000), process tools represent 35\% of electricity consumption in semiconductor fabrication.

The top-down approach also presents the interest of not specifically focusing on a particular chip family and therefore avoids drawing conclusions on marginal chip families. Using a top-down approach is only relevant because industrial activities are homogenous in all front- and back-end plants. In front-end plants, silicon wafers are processed in iterative homogenous cycles of surface treatment, called mask levels. Any component can be seen as a series of mask levels and its complexity is directly dependant of the number of masks. In back-end plants, there are about 20 families of packages. Within each family, only the size and number of interconnections (pins or balls) differ. This provides a very simple way to describe the environmental burden with a unique parameter characterizing both production and technology: the number of masks in the front-end and the number of pins in the backend.

The input inventories of typical front-end and back-end processes are presented in Tables 4-a and b (Villard, 2009).

Table 4-a. Input Inventory of a Typical Front-End Plant Process (approximations based on Villard, 2009)

\begin{tabular}{|l|l|l|}
\hline FRONT-END: DIE & 70 & $\mathrm{MG}$ \\
\hline Silicon & 70 & $\mathrm{mg}$ \\
\hline Chemicals & 25000 & $\mathrm{mg}$ \\
\hline Electricity/heat & 1000 & $\mathrm{Wh}$ \\
\hline Water, river & 10 & $\mathrm{l}$ \\
\hline Transport die & 0,1 & $\mathrm{~kg} \mathrm{~km}$ \\
\hline Emissions to air & 80 & $\mathrm{~g}$ \\
\hline Emissions to water & 0,1 & $\mathrm{~g}$ \\
\hline Waste & 10 & $\mathrm{~g}$ \\
\hline
\end{tabular}

Table 4-b. Input Inventory of a Typical Back-End Plant Process (Villard, 2009)

\begin{tabular}{|l|l|l|}
\hline BACK-END : CHIP & 4500 & $\mathrm{MG}$ \\
\hline Metals & 1500 & $\mathrm{mg}$ \\
\hline Chemicals/Plastics/Minerals & 600 & $\mathrm{mg}$ \\
\hline Resin/epoxy & 2000 & $\mathrm{mg}$ \\
\hline Electricity & 200 & $\mathrm{Wh}$ \\
\hline Indirect chemicals & 60 & $\mathrm{mg}$ \\
\hline Raw Water & 100 & 1 \\
\hline Transport & 50 & $\mathrm{~kg} \mathrm{~km}$ \\
\hline Emissions water & 1 & $\mathrm{mg}$ \\
\hline Emissions air & 100 & $\mathrm{mg}$ \\
\hline Waste & 5 & $\mathrm{~g}$ \\
\hline
\end{tabular}

As production is also comparable from one plant to another, the conclusions can be extended to the whole industry. Environmental management systems applied to sites help understand the evolution, the problems and the most significant pollutions that can be attributed to industrial activities. In ISO 14000 certification, a list of significant aspects is regularly updated in function of severity, frequency, control and sensitivity of the environment. These aspects are related to air, water, soil or waste, and are

11 TRACI: Tool for the Reduction and Assessment of Chemical and other Environmental Impacts http://www.earthshift.com/software/simapro/traci2 
generated by the plant itself, the processes or the activities. The lists are shown in Tables 5-a and b respectively for front-end and back-end manufacturing sites. The significant aspects observed in the top-down approach on the macroscopic scale of a microelectronic plant are representative for a single component and the results can therefore be compared to the chip in a bottom-up approach (Section 3.3).

Table 5-a. Significant input and output flows and their influence on the environment in front-end sites

\begin{tabular}{|c|c|c|}
\hline $\begin{array}{l}\text { INPUT AND OUTPUT FLOWS } \\
\text { INFLUENCING THE } \\
\text { ENVIRONMENT }\end{array}$ & ASPECTS & STATE CHANGE \\
\hline $\begin{array}{l}\text { Liquid substances containing } \\
\text { metals and toxic compounds }\end{array}$ & Toxic compounds in wastewater & \multirow{6}{*}{$\begin{array}{l}\text { Degraded water quality: toxicity, } \\
\text { acidification, modification of } \\
\text { composition, eutrophication }\end{array}$} \\
\hline Acids & $\begin{array}{l}\text { Chlorine, Fluor, nitrogen and } \\
\text { phosphorous compounds in } \\
\text { wastewater, water pH change }\end{array}$ & \\
\hline Bases & $\begin{array}{l}\text { Nitrogen compounds in wastewater, } \\
\text { water } \mathrm{pH} \text { change }\end{array}$ & \\
\hline $\begin{array}{l}\text { Nitrogenous \& phosphorous } \\
\text { substances }\end{array}$ & $\begin{array}{l}\text { Phosphorous and Nitrogen } \\
\text { compounds in wastewater }\end{array}$ & \\
\hline Silicon products & Silica compounds in wastewater & \\
\hline Fluor compounds & Fluor compounds in wastewater & \\
\hline Organic compounds & VOC formation & $\begin{array}{l}\text { Degraded air quality } \\
\text { Effects on local summer smog }\end{array}$ \\
\hline PFC, SF6 & $\begin{array}{l}\text { Direct emissions of greenhouse } \\
\text { gases }\end{array}$ & Greenhouse gases released \\
\hline Toxic gases and liquids & $\begin{array}{l}\text { Doping gases (silane, phosphine, } \\
\text { diborane) } \\
\text { Liquids for photolithography } \\
\text { (acetone, tetramethylammonium } \\
\text { hydroxide) } \\
\text { Etchants (nitrous oxide, chlorine, } \\
\text { boron trichloride) }\end{array}$ & $\begin{array}{l}\text { Toxicity for eco-systems in air and } \\
\text { water }\end{array}$ \\
\hline Solvents / liquid acids & $\begin{array}{l}\text { Hazardous waste } \\
\text { Emissions of CO }\end{array}$ & $\begin{array}{l}\text { Hazardous waste } \\
\text { Effects on local summer smog }\end{array}$ \\
\hline $\begin{array}{l}\text { Infrastructures (boilers, air } \\
\text { treatment units) }\end{array}$ & Emissions of NOX and VOC & $\begin{array}{l}\text { Degraded air quality } \\
\text { Effects on local summer smog }\end{array}$ \\
\hline Energy (tools, facilities) & Intensive electricity consumption & Indirect effects due to energy use \\
\hline Ultra Pure Water consumption & Intensive water usage & Increased water stress \\
\hline
\end{tabular}

Table 5-b. Significant input and output flows and their influence on the environment in back-end sites

\begin{tabular}{|l|l|l|}
\hline $\begin{array}{l}\text { INPUT AND OUTPUT FLOWS } \\
\text { INFLUENCING THE } \\
\text { ENVIRONMENT }\end{array}$ & ASPECTS & STATE CHANGE \\
\hline Metals & Toxic compounds in wastewater & Degraded water quality \\
\hline Plastics & Plastic waste & Waste \\
\hline Organic compounds & VOC formation & $\begin{array}{l}\text { Degraded air quality } \\
\text { Effects on local summer smog }\end{array}$ \\
\hline Energy (equipment and facilities) & Intensive electricity consumption & Indirect effects due to energy use \\
\hline
\end{tabular}

\subsection{Impacts of the up-phase value chain}

The up-phase value chain is the supply chain producing inputs for the manufacturing plant. A bottomup approach to the environmental assessment of semi-conductor manufacturing considers a particular chip family by studying the input and output flows of each step in production. In a bottom-up approach of the supply chain, the focus is on the quantities of raw materials used in the manufacturing process without considering manufacturing plants performances. Results of the analysis of the supply chain can be found in literature.

In key LCA-related papers (Schischke et al., 2001; Williams et al., 2002; Smati et al., 2001), the impacts underlined were related to global warming, water and energy use. Cullen et al. (2001) placed global warming, energetic resources depletion and particle emissions as the most significant aspects. Besides, for Chang and Kim (2011), the different chemicals used in considerable amounts during chip manufacturing were responsible for effects on toxicity of eco-systems and health.

Most of these papers consider a restrictive set of environmental aspects. However, a state of the art permits to highlight the most damaging items of the supply chain (Table 6). Our internal case study 
highlighted a particular environmental aspect: rare gas production, used during manufacturing (helium and argon in vacuums of etching and Chemical Vapour Deposition (CVD) and xenon used during ionic implantation).

Table 6. Literature studies of raw material contributions from up-phase manufacturing of a typical product

\begin{tabular}{|l|l|}
\hline $\begin{array}{l}\text { INPUT AND OUTPUT FLOWS } \\
\text { INFLUENCING THE ENVIRONMENT }\end{array}$ & SOURCES \\
\hline Electricity production & $\begin{array}{l}\text { Schischke et al., 2001; Williams et al. 2002; Liu et al., } \\
\text { 2010; Higgs et al. 2009, Andrae and Andersen 2004 }\end{array}$ \\
\hline Metals production & Andrae and Anderson 2004 \\
\hline Bulk gas production & Chang and Kim 2011, Higgs 2009, Schischke et al. 2004 \\
\hline Organic chemicals & Chang and Kim 2011 \\
\hline Ultrapure water production & Taiariol et al. 2001, Schischke et al. 20 \\
\hline Ultrapure products & Higgs 2009 \\
\hline PFC gas production & Liu et al. 2010 \\
\hline Silicon substrate production & Higgs2009 \\
\hline Package substrate production & Higgs2009 \\
\hline Rare gas production & In-house study \\
\hline
\end{tabular}

The aspects identified will modify the state of the surrounding environment. This requires understanding how these forces contribute to the state of the environment and so what indicators should be used to characterise their effects. A review on different sectors (mining, chemistry, electricity producers) helps to define the main aspects of raw material production (Table 7). The relative impacts of raw materials are characterised by scores from databases like CML ${ }^{12}$, TRACI or USEtox ${ }^{13}$ using Eco-Invent ${ }^{14}$ items.

Table 7. Literature studies and environmental impacts during up-phase production of raw materials

\begin{tabular}{|l|l|l|}
\hline PRODUCTION OF: & DIRECT EFFECTS & SOURCES \\
\hline \multirow{2}{*}{ Electricity } & $\begin{array}{l}\text { Environmental pressure due to fossil fuels: } \\
\text {-energetic resource depletion } \\
\text {-greenhouse effect gas emission due to fuel } \\
\text { combustion } \\
\text {-pollutant emissions into the atmosphere: acidifying } \\
\text { substances, particles and tropospheric ozone } \\
\text { precursors } \\
\text {-oil discharge }\end{array}$ & $\begin{array}{l}\text { European Energy Agency, 2006 } \\
\text { Dincer, 1999 }\end{array}$ \\
\hline Metals & Resources depletion, toxicity, acidification & $\begin{array}{l}\text { Salomons 1995; Pizzol, 2011; } \\
\text { Norgate, 2007 }\end{array}$ \\
\hline $\begin{array}{l}\text { Bulk gases (nitrogen, } \\
\text { hydrogen and } \\
\text { oxygen) }\end{array}$ & $\begin{array}{l}\text { Electricity consumption during energy-consuming } \\
\text { cryogenic processes }\end{array}$ & Smith and Klosek, 2001 \\
\hline Organic chemicals & Photochemical oxidation, global warming & Bowman and Seinfeld, 1994 \\
\hline Ultrapure water & $\begin{array}{l}\text { Eutrophication (use of chemical products) } \\
\text { Electricity consumption during purification phase }\end{array}$ & $\begin{array}{l}\text { STMicroelectronics: performances } \\
\text { of ultrapure water station }\end{array}$ \\
\hline $\begin{array}{l}\text { Ultrapure liquid } \\
\text { chemicals }\end{array}$ & Water and air pollution (various phenomena) & $\begin{array}{l}\text { Weidenhaupt and Hungerbühler, } \\
1997\end{array}$ \\
\cline { 2 - 3 } & Electricity consumption during purification phase & Williams 2002 \\
\hline PFC gases & Global warming, toxicity & Tsai, 2002 \\
\hline Silicon wafer & $\begin{array}{l}\text { Electricity consumption during energy-consuming } \\
\text { process }\end{array}$ & Duque Ciceri, 2010 \\
\hline Package substrate & $\begin{array}{l}\text { Electricity consumption during energy-consuming } \\
\text { process }\end{array}$ & Duque Ciceri, 2010 \\
\hline Rare gases & Resources depletion & CML \\
\hline
\end{tabular}

\subsection{Impact of the down-phases}

The down-phases of the value chain are situated after the manufacturing plant and include the electronic application: chip distribution, use and disposal.

${ }^{12}$ CML: Chain Management by Life Cycle Assessment - http://www.cmlca.eu/

${ }^{13}$ UseTOX: http://www.usetox.org/

${ }^{14}$ Eco-Invent: http://www.ecoinvent.org/database/ 
The effects of use phase are due to emissions generated by electricity consumed in the final application. Product disposal issues are linked to the end of life treatment of heavy metals: lixiviation of metals in landfill leading to soil pollution and metals released into the atmosphere after incineration. LCA showed that for all disposal scenarios, including the worst cases, the impact of end of life represents less than $0.1 \%$ of the total impact and can therefore be neglected (fig. 2).

Concerning transport of the product itself, wafers are transported from front-end sites to back-end sites. According to sectorial roadmaps, wafer diameter increases while component size decreases and there is a similar trend for packaging with less mass and volume. Finally the environmental contribution of inhouse distribution remains a feeble part of the total impact of the product life cycle. Table 8 summarises the effects of the other life cycle phases.

Table 8. Input and output flows and environmental impacts during down-phases

\begin{tabular}{|c|c|c|}
\hline $\begin{array}{c}\text { INPUT AND OUTPUT FLOWS } \\
\text { INFLUENCING THE } \\
\text { ENVIRONMENT }\end{array}$ & ASPECTS & STATE CHANGE \\
\hline Electricity consumption & $\begin{array}{c}\text { Electricity } \\
\text { production }\end{array}$ & $\begin{array}{c}\text { Impacts linked to electricity } \\
\text { production }\end{array}$ \\
\hline Electronic waste & Neglected & Neglected \\
\hline Transportation & Neglected & Neglected \\
\hline
\end{tabular}

\subsection{Rare Earth Elements}

As mentioned in section 2.4, impacts of REEs are currently neglected in the semiconductor industry because of the very small quantities used compared with other industrial sectors. REEs are automatically taken into consideration in LCA software like Simapro. However their impacts are differently included in impact calculation methods (for example, CML considers them) although this question is not specific to semiconductor products. In the future REEs in the industry should be surveyed if their use is considerably increased and the recycling of REEs in microelectronic products should be accounted for (though abiotic depletion indicators and water resources for example.

\section{Environmental hot-spots}

The previous section identified the aspects for which the environmental impacts must necessarily be considered. This section summarises the different impacts of semi-conductor manufacturing across the important life cycle stages and selects a reduced set of significant impact categories that cover all the issues that should be monitored. Next, the relevance of each impact category is carefully analysed. Indeed, one particular effect can be of more importance than others. Additionally, the same information can be considered twice leading to difficulties in the interpretation of LCA results and incorrect monitoring of performance.

\subsection{Significant environmental impact categories}

Table 9 starts by listing the main contributors to each impact category and indicates the life cycle phases that are concerned. 
Table 9. Main flows and life cycle phases contributing to impact categories

\begin{tabular}{|c|c|c|c|c|}
\hline $\begin{array}{l}\text { IMPACT } \\
\text { CATEGORIES }\end{array}$ & $\begin{array}{l}\text { INPUT AND OUTPUT FLOWS INFLUENCING } \\
\text { THE ENVIRONMENT }\end{array}$ & $\begin{array}{l}\text { SUPPLY } \\
\text { CHAIN }\end{array}$ & $\begin{array}{l}\text { MANUFAC } \\
\text { TURING }\end{array}$ & USE \\
\hline Global warming & PFC gases, electricity & $\mathrm{x}$ & $\mathrm{x}$ & $\mathrm{x}$ \\
\hline Resource depletion & Rare gases, metals, electricity & $\mathrm{x}$ & & $\mathrm{x}$ \\
\hline Water stress & Ultrapure water production from tape water & & $\mathrm{x}$ & \\
\hline Local summer smog & $\begin{array}{l}\text { Organic compounds, solvents, infrastructures, } \\
\text { electricity (particles) }\end{array}$ & $\mathrm{x}$ & $\mathrm{x}$ & $\mathrm{x}$ \\
\hline Eutrophication & $\begin{array}{l}\text { Ultrapure water, nitrogenous and phosphorous } \\
\text { liquids }\end{array}$ & $\mathrm{x}$ & $\mathrm{x}$ & \\
\hline $\begin{array}{l}\text { Toxicity (aquatic, } \\
\text { human) }\end{array}$ & Metals, toxic compounds in liquids, toxic gases & $\mathrm{x}$ & $\mathrm{x}$ & \\
\hline Acidification & $\begin{array}{l}\text { Ultrapure chemicals, ultrapure water, metal (copper), } \\
\text { acids, bases, electricity }\end{array}$ & $\mathrm{x}$ & & $\mathrm{x}$ \\
\hline $\begin{array}{l}\text { Modification of water } \\
\text { composition }\end{array}$ & $\begin{array}{l}\text { Liquid substances: containing metals and toxic } \\
\text { compounds, acids, bases, silicon products, fluorine } \\
\text { compounds }\end{array}$ & & $\mathrm{x}$ & \\
\hline Hazardous waste & Solvents / liquid acids & & $\mathrm{x}$ & \\
\hline Waste (part of) & Plastics & & $\mathrm{x}$ & \\
\hline
\end{tabular}

It is now possible to choose a set of significant impact categories for the microelectronic industry.

A first set of categories is easy to define because it re-joins sectorial concerns on LCA: "global warming", "resources depletion" and "water stress".

"Local summer smog" is also very relevant because it is the only category that takes into account the effects of the production and consumption of solvents and all the organic compounds. It also highlights one of the major issues of the production of electricity.

"Eutrophication" is relevant too, because it takes into account the use of chemicals and ultrapure water in manufacturing.

Secondly, three categories "eco-toxicity", "acidification" and "modification of water composition" are highlighted to qualify the effects of chips on water quality. They all respond to the extensive use of hazardous chemicals in semi-conductor manufacturing.

It should be noted that the plants have no direct effect on "water acidification". Even though manufacturers are big consumers of acids in the wet cleaning processes for wafers, they generally end up eliminated in wastewater treatment plants.

The effects of the use of metals are highlighted by the second set of categories. Direct risks of toxicity are limited for workers and final users. The main direct risk linked to metals is their potential rejection to water so it is better to focus on water toxicity or human toxicity. Extensive needs for mineral extraction appears strongly in the first set of impact categories, under "resource depletion".

However, some metals, especially copper, have a strong effect on acidification but these effects can also be taken into account in "toxicity", whereas indirect effects of liquid chemicals (acids and bases) are considered in the categories: "eutrophication" and "toxicity".

Water composition, directly linked to the preservation of neighbouring eco-systems, is modified by microelectronic activities and also, presumably, by supplier activities. However, the main influences are already taken into account through "eutrophication" and "toxicity". The effects of silicon and fluor emissions in water are not extremely serious issues compared to phenomenon linked to toxicity in water (contamination of eco-systems) or eutrophication (deoxygenation of aquatic eco-systems).

Finally, the effects of waste could be considered. However, according to Ernst (2011), an overview of the quantity of waste in manufacturing business shows that the consideration of waste in microelectronic industry is not really legitimate compared to other industrial sectors, all the more seeing that the recycling rate of plastic parts in back-end sites is improving. Furthermore, the risks of solvents and liquids are already taken into account in "summer smog" and the consideration as waste would therefore become redundant.

In conclusion, we propose to retain six of the ten initial impact categories that cover all the important sources of impacts: global warming, resource depletion, water stress, local summer smog, eutrophication and toxicity.

\subsection{Considerations for suitable indicators}

For each impact category, different indicators are currently available. Some of them have led to international consensus and others have advantages and drawbacks which must be taken into consideration. The selection of a particular model is neither a certification of the model, nor does it 
necessarily mean that it is the best available. ISO 14031, ISO 14044 and SETAC ${ }^{15}$ working groups (Dreyer and Niemann, 2003) defined criteria for their evaluation that should be used to select indicators. Their proposals can be applied to the microelectronic sector. In this section, some additional more specific suggestions are proposed.

\section{Resource depletion}

The models for resource consumption and depletion can be very different according the life cycle impact assessment methods used. In our case, this category should be related to the extraction of minerals and fossil fuels, both energetic and mineral resources from ground, water and air, and including the use of rare materials (gases: xenon, argon and helium; and metals: palladium and gold). To monitor electricity consumption during manufacturing, we prone the use of local electricity consumption, in mega joules, so as to compare energy performances of plants irrespectively of their location and the local energy mix. This indicator reflects the important issue concerning the control of electricity consumption during manufacturing and helps to define the most energy-demanding manufacturing steps. Indeed the local energy mix which the microelectronic industry is not necessarily responsible for tends to bias the interpretation of the electrical consumption of the manufacturing processes. This is especially true as the local energy mix efficiency is already taken into account in global warming reporting.

\section{Water stress}

Water stress results from the imbalance between water use and water resources and causes deterioration of fresh water resources in terms of quantity (aquifer over-exploitation, dry rivers, etc.) and quality (eutrophication, organic matter pollution, saline intrusion, etc.). Water consumption in temperate zones induces less critical impacts than in arid climatic zones where water becomes scarce and the resources available for exploitation and provision to populations are not equivalent. The water stress indicator measures the proportion of water withdrawal with respect to total renewable resources (Alcamo et al., 2000). It is a criticality ratio, which implies that water stress depends on the variability of resources. However, today, no indicator on water stress in terms of environmental impacts has yet been developed. Consequently, the only reasonable indicator available for use today is the imported volume of raw water. The ultra-pure water is taken into account because raw water is transformed directly in the plant's ultrapure water generator.

\section{Toxicity}

Toxicity is measured regarding impacts on eco-systems or on human health. We advise the use of human health indicators because the risk assessment of chemicals is a real issue facing the microelectronic industry. The growing importance of these issues is reflected by recent accent on REACH and RoHS legislations in Europe and the rest of the world.

\subsection{A final set of indicators}

The six impact categories identified above can be resumed by a set of seven indicators. Table 10 lists them and shows the major reasons for their choice as indicators suitable to draw the environmental profile of a chip.

\footnotetext{
${ }^{15}$ SETAC: Society of Environmental Toxicology and Chemistry - http://www.setac.org
} 
Table 10. Final set of indicators and their relevance in the microelectronic industry

\begin{tabular}{|l|l|}
\hline $\begin{array}{l}\text { INDICATORS FOR IMPACT } \\
\text { ASSESSMENT }\end{array}$ & RELEVANCE \\
\hline Global Warming & $\begin{array}{l}\text { It is the most common indicator used to report on environmental changes. In } \\
\text { the microelectronic industry it is all the more important that there is a huge } \\
\text { amount of electricity consumed throughout the life cycle, including raw } \\
\text { material extraction, energy intensive production processes and the use of the } \\
\text { final product in an application. Moreover, a considerable quantity of PFCs is } \\
\text { consumed during manufacturing. }\end{array}$ \\
\hline Abiotic depletion & $\begin{array}{l}\text { Chip manufacturing consumes both energy and mineral resources (table 1). } \\
\text { Other than coal, rare gases, precious metals and REEs should be mentioned. } \\
\text { It is a crucial topic for the whole electronic industry. }\end{array}$ \\
\hline Water eutrophication & $\begin{array}{l}\text { The quality of water surrounding microelectronic plants is largely damaged } \\
\text { by intensive usage of nitrogen and phosphorous acids, especially in wet } \\
\text { cleaning processes. }\end{array}$ \\
\hline Imported volume of raw water & $\begin{array}{l}\text { Stress on water is mainly due to ultrapure water used for production and } \\
\text { general plant functioning. Manufacturers are more and more challenged on } \\
\text { water control issues. }\end{array}$ \\
\hline Human eco-toxicity & $\begin{array}{l}\text { Manufacturing, especially the package, rejects a large range of metals, in } \\
\text { different physical forms (particulate and solid). The release of metals in } \\
\text { water induces potential effects on toxicity. This indicator showed the } \\
\text { beneficial effect of the RoHS legislation. Other specific liquids (resins, } \\
\text { solvents, silicon products, bases and acids) must be controlled regarding } \\
\text { potential toxic effects during manufacturing and use in plants. }\end{array}$ \\
\hline Summer smog & $\begin{array}{l}\text { Several steps of wafer and package processing consume solvents producing } \\
\text { VOCs and plant facilities damage the quality of air (boilers, air refrigerators). } \\
\text { Summer smog (or photochemical oxidation) accounts for these pollutions. }\end{array}$ \\
\hline Local electrical consumption & $\begin{array}{l}\text { This indicator is the most suitable to account for the total energy consumed } \\
\text { by equipments and facilities during manufacturing. It helps to identify } \\
\text { hotspots. }\end{array}$ \\
\hline
\end{tabular}

\section{Conclusion}

This paper draws an environmental profile of products in the microelectronic industry. It proposes a reduced set of seven environmental indicators that cover the most significant effects on the environment caused during the life cycle of semiconductors. The indicators are global warming, abiotic depletion, and water eutrophication, imported volume of raw water, human eco-toxicity, summer smog and local electrical consumption. The indicators have been derived from practical considerations and observations in existing semiconductor front-end and back-end plants combined with information from databases, when they are sufficient, for stabilized processes. They also account for general profiles of product use and disposal. They can effectively be used to cover all the stages in semiconductor chip manufacturing.

The set of indicators will help construct more robust and systematic assessment methodologies for the semiconductor industry. This approach satisfies growing concerns expressed by stakeholders including issues on chemicals, global warming and water and energy consumption as suggested in the industry's roadmaps. The indicators can be used to assess and improve environmental performances of semiconductor products in a full life cycle and multi-indicator prospective.

In line with ISO environmental recommendations, eco-design in the microelectronic industry must account for complete life cycle impacts, and be used in a systematic approach to chip design. LCA will help decision-making when it provides accurate indications covering the large spectrum of environmental effects and can be used during design phases. In this sense the paper encourages the industry to move a step further from current semiconductor roadmaps and establish a consistent policy of standard multi-indicators integrating the full life cycle of its' products.

Reducing the number of indicators to the most significant ones will strongly contribute to fixing priorities for environmental strategies. Drawing a profile of the impacts generated by the microelectronic chips can help making design decisions and determine the effectiveness of proposed solutions. During the chip lifecycles, the paper points out that the most significant aspects are linked to climate change, abiotic depletion, human toxicity, eutrophication and summer smog. These categories are attributed to heavy energy-demanding manufacturing process flows which consume and release large quantities of different chemicals (metals, acids, solvents). Besides these, energy flows (MJ) and water consumption $\left(\mathrm{m}^{3}\right)$ in equipment and facilities during manufacturing are also relevant indicators. In the current state of art, the paper recommends that the microelectronic industry limit environmental analysis to these indicators. A reduced set of standardized significant indicators will more effectively 
underline environmental pressures caused by the industry and contribute to understanding the major causes of these impacts. They will also help control potential impact transfers, from one impact category to another and from one life cycle phase to another. In this way, the indicators contribute to building and driving environmental strategies. Impact assessment should therefore focus on these categories.

In conclusion, a standardized method for the environmental characterization of micro-chip technologies is necessary to compare the performance of different products and specify product profiles. A suitable set of LCA indicators strongly contributes to increase life cycle knowledge of the chips. They must be accepted by the international scientific community, be stable and induce reasonable and constructive remarks on the main contributors to impacts. In this paper, a set of seven indicators are proposed, consistent with current state of art, but they can be expected to evolve as new methods and indicators, such as biodiversity or water stress, become available in LCA software. This paper argues for the development of standard indicators leading to an international consensus, such as the case of global warming. Finally, the definition of a standard for indicators must be associated with the creation of similar standards for other LCA aspects: LCI, impact assessment methods, interpretation of results and publication.

\section{References}

Alcamo, J., Henrichs, T., Rösch, T., 2000. World water in 2025: global modeling and scenario analysis, ed F.R. Rijsberman, World Water Scenarios Analyses, Earthscan Publications, London, 396.

Andræ, A.S.G., Andersen, O., 2004. Life cycle assessment of integrated circuit packaging technologies. Int J Life Cycle Assess 16 (3), 258-267.

Bare, J. C., 2002. Traci. Journal of Industrial Ecology, 6(3-4), 49-78.

Bleiwas, D.I., Gambogi, J., 2013, Preliminary Estimates of the Quantities of Rare-Earth Elements Contained in Selected Products and in Imports of Semimanufactured Products to the United States, 2010, US Geological Survey Open-File Report 2013-1072, 14p., http//pubs.usgs.gov/of/2013/1072/

Binnemans, K., Jones, P. T., Blanpain, B., Van Gerven, T., Yang, Y., Walton, A., Buchert, M., 2013. Recycling of rare earths: a critical review. Journal of Cleaner Production, 51, 1-22

Bonvoisin, J., Lelah, A., Mathieux, F., Brissaud, D., 2014. An integrated method for environmental assessment and ecodesign of ICT-based optimization services. Journal of Cleaner Production. doi:10.1016/j.jclepro.2014.01.003

Bowman, F.M., Seinfeld, J.H., 1994. Ozone productivity of atmospheric organics. Journal of Geophysical Research 99, D3, 5309-5324.

Boyd, S., Horvath, A., Dornfeld, DA., 2010. Life-cycle assessment of computational logic produced from 1995 through 2010. Environ. Res. Lett., 5 (1).

Chang, IS., Kim J.H., 2001. Development of clean technology in wafer drying processes. Journal of Cleaner Production 9 (3), 227-232.

Cullen, MR, Checkoway, H., Eisen, E.A., Kelsey, K., Rice C., Wegman D.H., 2001. Cancer risk among wafer fabrication workers in the semiconductor industry evaluation of existing data and recommended future research. http://www.sia-online.org/clientuploads/SAC_Summary.pdf (accessed 27.03.14).

De Benedetto, L., and Klemeš, J., 2009. The Environmental Performance Strategy Map: an integrated LCA approach to support the strategic decision-making process. Journal of Cleaner Production, 17(10), 900-906.

Dickinson, DA., 2002. Application of the sustainability target method: supply line case studies. IEEE International Symposium on Electronics and the Environment, 139-143.

Dincer, I. 1999. Environmental impacts of energy. Energy Policy 27, 14, 845-854.

Dreyer, L.C., Niemann, A.L., 2003. Comparison of three different LCIA methods: EDIP97, CML2001 and ECO-indicator99. International Journal of Life Cycle Assessment 8, 191-200.

Duque Ciceri, N., Gutowski, T. G., Garetti, M., 2010. A Tool to Estimate Materials and Manufacturing Energy for a Product. IEEE, International Symposium on Sustainable Systems and Technology, 1-6.

Ernst, E., 2011. La production de déchets non dangereux dans l'industrie manufacturière en 2008. (in French) http://www.insee.fr/fr/ffc/ipweb/ip1335/ip1335.pdf (accessed 27.03.14).

European Commission, 2002a. Directive 2002/95/EC: Restriction of the use of certain hazardous substances in electrical and electronic equipment, Brussels, Belgium.

European Commission, 2002b. Directive 2002/96/EC: Waste electrical and electronic equipment, Brussels, Belgium.

European Commission, 2002c. Directive 2002/53/EC: End-of-life vehicules, Brussels, Belgium.

European Commission, 2005. Directive 2002/32/EC on energy end-use efficiency and energy services, Brussels, Belgium. 
European Energy Agency, 2006. Energy and environment in the European Union Tracking progress towards integration. http://www.eea.europa.eu/publications/eea_report_2006_8 (accessed 27.03.14).

Gehin, A., Zwolinski, P., Brissaud, D., 2008. A tool to implement sustainable end-of-life strategies in the product development phase. Journal of Cleaner Production 16, 5, 566-576.

Golev, A., Scott, M., Erskine, P. D., Ali, S. H., \& Ballantyne, G. R. (2014). Rare earths supply chains: Current status, constraints and opportunities. Resources Policy, 41, 52-59.

Higgs, T., Cullen, M., Yao M., Stewart, S., 2009. Developing an overall CO2 footprint for semiconductor products. IEEE International Symposium on Sustainable Systems and Technology, 1-6.

International Telecommunication Union, 2010. ICTs and Environmental Sustainability. 5th ITU Symposium. www.itu.int/dms_pub/itu-t/oth/06/0F/T060F0060160001PDFE.pdf (accessed 27.03.14).

ISO, 1999. ISO14031: Environmental Management: Environmental Performance Evaluation Guidelines, ISO13031:1999(E). $1^{\text {st }}$ ed. Geneva, Switzerland

ITRS, 2013. International Technology Roadmap for Semiconductors, 2013 Edition, Environment, Safety, and Health Summary. http://www.itrs.net/Links/2013ITRS/Summary2013.htm (accessed 07.05.14).

Iwai, H., Ohmi, S., 2002. Silicon integrated circuit technology from past to future. Microelectronics Reliability, 42(4-5), 465-491

Lawrence Berkeley National Laboratory, 2000. Energy Efficiency in Semiconductor Cleanrooms: A Technical Perspective. http://ateam.lbl.gov/cleanroom/technical.html (accessed 27.03.14).

Liu, CH., Lin, S.J., Lewis, C., 2010. Life cycle assessment of DRAM in Taiwan's semiconductor industry. Journal of Cleaner Production 18 (5), 419-425.

Long, K.R., 2011. The future of rare earth elements, USGS, http://fr.slideshare.net/Tehama/usgsthe-future-of-rare-earth-elements

Lütz, M., Felici, F., 2008. Indicators to identify the agricultural pressures on environmental functions and their use in the development of agri-environmental measures. Reg Environ Change 9 (3), 181-196.

Minx, J. C., Wiedmann, T., Wood, R., Peters, G. P., Lenzen, M., Owen, A., Scott, K., Barrett, J., Hubacek, K., BAIOCCHI, G., Paul, A., Dawkins, E., Briggs, J., Guan, D., Suh, S., Ackerman, F., 2009. Input-Output Analysis and Carbon Footprinting: An Overview of Applications. Economic Systems Research, 21(3), 187-216.

Norgate, T.E., Jahanshahi, S., Rankin, W.J., 2007. Assessing the environmental impact of metal production processes. Journal of Cleaner Production 15 (8-9), 838-848.

Olsthoorn, X., Tyteca, D., Wehrmeyer, W., Wagner, M., 2001. Environmental indicators for business: a review of the literature and standardisation method. J Clean Prod 9, 453-463.

Pizzol, M. Christensen, P., Schmidt, J., Thomsen, M., 2011. Eco-toxicological impact of "metals" on the aquatic and terrestrial ecosystem: A comparison between eight different methodologies for Life Cycle Impact Assessment (LCIA), Journal of Cleaner Production, 19 (6-7), 687-698.

Plepys, A., 2004. The environmental impacts of electronics. Going beyond the walls of semiconductor fabs. IEEE Electronics and the Environment, 159-165.

Salomons, W., 1995. Environmental impact of metals derived from mining activities: Processes, predictions, prevention. Journal of Geochemical Exploration 52 (1-2), 5-23.

Schaller, RR., 1997. Moore's law: past, present and future. IEEE Spectrum 34, 52-59.

Schischke, K., Stutz, M., Ruelle, J.P., Griese, H., Reichi H., 2001. Life cycle inventory analysis and identification of environmentally significant aspects in semiconductor manufacturing. IEEE Electronics and the Environment, 145-150.

Schischke, K., Griese, H., 2004. Is small green? Life Cycle Aspects of Technology Trends in Microelectronics and Microsystems LCA Center, http://www.lcacenter.org/InLCA2004/papers/Schischke_K_paper.pdf (accessed 27.03.14).

Schmidt, M., Hottenroth, H., Schottler, M., Fetzer, G., Schlüter, B., 2011. Life Cycle Assessment of Silicon Wafer Processing for Microelectronic Chips and Solar Cells, International Journal of Life Cycle Assessment, 17(2), 126-144.

Scipioni, A., Manzardo, A., Mazzi, A., Mastrobuono, M., 2012. Monitoring the carbon footprint of products: a methodological proposal. Journal of Cleaner Production, 36, 94-101.

SEMATECH, 2002. Life Cycle Assessment (LCA) White Paper. www.sematech.org/docubase/document/4238atr.pdf (accessed 27.03.14).

SEMATECH, 2009. Semiconductor Key Environment Performance Indicators Guidance. www.sematech.org/docubase/document/5069aeng.pdf (accessed 27.03.14).

Smati, R., Raoux, S., Ho, D., Woolston, M., 2001. Measuring and modeling gas consumption and emissions from semiconductor manufacturing processes. EHS Assessment Techniques, SEMICON West. 
Smith, A.R, Klosek, J., 2001, A review of air separation technologies and their integration with energy conversion processes, Fuel Processing Technology, 70 (2), 115-134.

Taiariol, F., Fea, P., Papuzza, C., Casalino, R., Galbiati, E., Zappa, S., 2001. Life cycle assessment of an integrated circuit product. IEEE Electronics and the Environment, 128-133.

Tsai, W.T., Horng-Ping Chen, Wu-Yuan Hsien, 2002. A review of uses, environmental hazards and recovery/recycle technologies of perfluorocarbons (PFCs) emissions from the semiconductor manufacturing processes. Journal of Loss Prevention in the Process Industries 15 (2), 65-75.

USGS, 2014, Mineral Commodity Summaries, 2014, http://minerals.usgs.gov/minerals/pubs/mcs/ (accessed 07.05.14)

Villard, A., 2009. Développement de méthodologies d'éco-conception pour le secteur microélectronique, Master Thesis, supervised by Brissaud, D., Grenoble, University of Grenoble-INP, 2009, 224 page (in French)

Weidenhaupt, A., Hungerbühler, K., 1997. Integrated Product Design in Chemical Industry. A Plea for Adequate Life-Cycle Screening Indicators, CHIMIA International Journal for Chemistry, 51 (5) 217-217.

Wiedmann, T., Minx, J., 2008. A Definition of 'Carbon Footprint'. In: Pertsova, C.C., Ecological Economics Research Trends: Chapter 1, Nova Science Publishers, Hauppauge NY, USA, 1-11

Williams, E.D., Ayres, R.U., Heller, M., 2002. The 1.7 kilogram microchip: energy and material use in the production of semiconductor devices. Environmental Science \& Technology 36, 5504-10.

Williams, E.D., 2004. Environmental impacts of microchip manufacture. Thin Solid Films 461, 2-6. 